\title{
Penerapan Lagu Tradisional “Ramadhan Suci” Karya KH. Fuad Hasyim untuk Meningkatkan Kemampuan Menulis Puisi Berorientasi Kearifan Lokal pada Siswa Kelas VIII MTs NU Putri 3 Buntet Pesantren Cirebon
}

\author{
Devi $^{1 凶}$, Indrya Mulyaningsih ${ }^{2} \&$ Emah Khuzaemah $^{3}$ \\ Institut Agama Islam Negeri Syekh Nurjati Cirebon \\ Devidv304@gmail.com, indrya.m@gmail.com, emah.kh69@gmail.com
}

\begin{abstract}
This study aims to describe the design of learning to write poetry through the application of traditional songs "Holy Ramadhan" by KH. Fuad Hasyim oriented to local wisdom in class VIII MTsNU Putri 3 Buntet Cirebon Islamic Boarding School and describe the ability to write poetry before and after traditional songs "Holy Ramadhan". The research method used is classroom action research. The main data source of this research is poetry work with the theme of local wisdom. The method of data collection is done by testing techniques, observation, interviews, field notes and documentation. The results showed that the results of the average score of the poetry writing test from the pre-action stage to the post-action cycle II had increased, namely: (1) at the pre-action stage, the overall value of the average student was 50.5. While the score on each aspect of the assessment indicator is 9.78. (2) at the stage of cycle I, the overall value of the average student increases to 72 . While the score on each aspect of the assessment indicator is 13.82. (3) in the second cycle stage, the overall value of the average student increases to 78.25. While the score on each aspect of the assessment indicator is 16.
\end{abstract}

Keywords: traditional songs, writing poetry, local wisdom

Abstrak : Penelitian ini bertujuan untuk mendeskripsikan desain pembelajaran menulis puisi melalui penerapan lagu tradisional "Ramadhan Suci" karya KH.Fuad Hasyim berorientasi kearifan lokal pada siswa kelas VIII MTsNU Putri 3 Buntet Pesantren Cirebon dan mendeskripsikan kemampuan menulis puisi sebelum dan sesudah diterapkan lagu tradisional "Ramadhan Suci". Metode penelitian yang digunakan adalah penelitian tindakan kelas. Hasil penelitian menunjukkan bahwa hasil skor rata-rata tes menulis puisi dari tahap pratindakan hingga pascatindakan siklus II mengalami peningkatan, yaitu: (1) pada tahap pratindakan, nilai keseluruhan ratarata siswa adalah 50,5. Sementara nilai skor pada tiap aspek indikator penilaian adalah 9,78. (2) pada tahap siklus I, nilai keseluruhan rata-rata siswa meningkat Sitasi Jurnal: menjadi 72. Sementara nilai skor pada tiap aspek indikator penilaian adalah 13,82.

Devi, D., Mulyaningsih, I., \& Khuzaemah, E. (2020). Penerapan Lagu Tradisional "Ramadhan Suci” Karya KH. Fuad Hasyim untuk MEeningkatkan Kemampuan Menulis Puisi Berorientasi Kearifan Lokal pada Siswa Kelas VIII MTsNU Putri 3 Buntet Pesantren Cirebon. Disastra: Jurnal Pendidikan Bahasa dan Sastra Indonesia, 2(1), 14-22. doi:http://dx.doi.org/10.29300/disastra.v2i1.1922 
(3) pada tahap siklus II, nilai keseluruhan rata-rata siswa semakin meningkat menjadi 78,25. Sementara nilai skor pada tiap aspek indikator penilaian adalah 16 .

Kata Kunci : lagu tradisional, menulis puisi, kearifan lokal

\section{Pendahuluan}

Usaha

pemerintah

untuk

menumbuhkan budaya menulis, yaitu dengan cara mencantumkan pada keterampilan berbahasa yang harus dikuasai oleh siswa. Orang tidak dapat berbicara jika tidak mampu menyimak dengan baik. Begitu pula dengan keterampilan membaca dan menulis, orang tidak akan mampu menulis jika tidak menguasai terlebih dahulu keterampilan membaca. Keterampilan membaca dan menulis merupakan jenis keterampilan produktif. Istilah produktif yaitu mampu menghasilkan sebuah karya secara berwujud, sedangkan keterampilan menyimak dan membaca merupakan jenis keterampilan reseptif. Istilah reseptif adalah mampu menerima dan menanggapi informasi berupa karya orang lain (Sulisetyowati, 2011:2).

Pembelajaran menulis puisi masih terdapat berbagai kelemahan. Kelemahan tersebut disebabkan antara lain; peserta didik merasa kesulitan dalam menulis puisi (baik puisi lama maupun puisi baru), hasil belajar yang berkaitan dengan pelajaran puisi kurang memuaskan, rendahnya ketertarikan peserta didik pada pelajaran bahasa Indonesia terutama dalam materi menulis puisi. Berdasarkan pendapat tersebut, dapat diketahui bahwa terdapat kelemahan dalam pembelajaran puisi bagi peserta didik. Dalam hal ini, perlu adanya upaya peningkatan kreativitas menulis bagi siswa terutama dalam materi puisi (Alfiah \& Santoso, 2009:4).
Berdasarkan hasil wawancara dengan guru bahasa Indonesia kelas VIII MTsNU Putri 3 Buntet Pesantren Cirebon, dapat diketahui bahwa keluhan siswa dalam mempelajari puisi adalah sulit menemukan kata-kata yang tepat. Salah satu faktor dalam hal ini kurangnya minat baca sehingga hasil belajar siswa menurun secara perlahan sekira $10 \%$ setiap tahunnya. Salah satu upaya yang pernah dilakukan oleh guru dalam meningkatkan keterampilan menulis puisi yaitu menggunakan media lagu yang disukai siswa, dengan catatan lagu yang dipilih harus terdapat banyak majas agar siswa mudah memperoleh kata dari lirik lagu tersebut untuk menambah kosakata dalam menciptakan puisi yang utuh.

Hasil belajar siswa melalui upaya pemanfaatan media lagu cukup efektif dan meningkat hingga $75 \%$ dibandingkan dengan upaya lainnya yang pernah dilakukan oleh guru seperti berjalan-jalan dan berkomunikasi antarteman. Oleh karena itu, yang menjadi fokus bahasan utama pada penelitian ini adalah memanfaatkan media lagu tradisional sebagai upaya meningkatkan kemampuan menulis dalam pembelajaran puisi. Penggunaan lagu tradisonal diharapkan siswa mampu menjunjung nilai kearifan budaya lokal yang memiliki nilai-nilai positif bagi kemampuan menulis puisi pada siswa MTs kelas VIII.

Lagu tradisonal dalam penelitian ini adalah lirik lagu "Ramadhan Suci" karya KH. Fuad Hasyim berasal dari daerah Buntet Pesantren Cirebon. Lagu tradisional tersebut dijadikan sebagai stimulan untuk merangsang imajinasi siswa dalam 
pembelajaran menulis puisi. Pemanfaatan lagu tradisional diharapkan agar siswa mampu mengambil nilai-nilai positif dari lagu tersebut dan diharapkan menghasilkan karya puisi yang bernilai dan bermakna positif. Lirik lagu "Ramadhan Suci yang berbahasa Cirebon ini bertujuan untuk memberikan pesan penting kepada masyarakat bahwa Ramadhan itu merupakan madrasah dan ladang sebagai pembinaan kepada masyarakat khususnya umat muslim untuk kembali sabar menahan dahaga dan lapar.

Mengacu pada uraian tersebut, penerapan lagu tradisional "Ramadhan Suci" karya KH. Fuad Hasyim pada pembelajaran menulis puisi diharapkan mampu meningkatkan kemampuan siswa dalam menulis puisi terutama sesuai dengan tema yang ditentukan, yaitu kearifan lokal. Oleh karena itu, penelitian ini mengangkat judul "Penerapan Lagu Tradisional 'Ramadhan Suci' Karya KH.Fuad Hasyim untuk Meningkatkan Kemampuan Menulis Puisi Berorientasi Kearifan Lokal pada Siswa Kelas VIII MTsNU Putri Buntet Pesantren Cirebon."

Penelitian ini dilengkapi teori yang mendukung dan berkaitan wilayah kajian dalam penelitian yang dilakukan, yaitu di antaranya membahas pengertian lagu, peningkatan kemampuan menulis, definisi menulis kreatif, hakikat puisi, serta kearifan budaya lokal. Adapun persamaan dengan penelitian terdahulu terletak pada subjek penelitian, yaitu sama-sama membahas karya puisi pada siswa SMP, sementara letak perbedaannya adalah puisi yang akan dikaji dalam penelitian ini diutamakan puisi yang bertema kearifan lokal sedangkan pada penelitian terdahulu hanya mengkaji karya puisi bebas.

\section{Metode Penelitian}

Jenis penelitian yang akan dilakukan adalah penelitian tindakan kelas, dalam hal ini bertujuan untuk mengetahui peningkatan hasil belajar siswa pada keterampilan menulis puisi berorientasi kearifan lokal dengan menggunakan media lagu. Adapun menurut Sukmadinata (2012:140) menyatakan bahwa penelitian tindakan kelas adalah suatu tahapan sistematik yang dilaksanakan oleh para peneliti program dalam kegiatannya sendiri untuk mengumpulkan data tentang pelaksanaan, keberhasilan dan hambatan yang dihadapi serta menyusun rencana kegiatan penyempurnaan. Adapun menurut Arikunto (2008: 17), desain model Kemmis dan McTaggrat meliputi empat tahap yaitu menyusun rancangan tindakan (planning), pelaksanaan tindakan (acting), pengamatan (observing), dan refleksi (reflecting).

Subjek penelitian ini adalah siswa kelas VIII C MTsNU Putri 3 Buntet Pesantren Cirebon berjumlah 43 siswa. Alasan dipilihnya kelas VIII C dibanding dengan kelas yang lain adalah karena setelah berdiskusi dengan guru bahasa Indonesia yang bernama Endah Ayu Fikriyyah, S.Pd. Diketahui bahwa siswa kelas VIII C cenderung pasif dalam menerima pelajaran dan tidak aktif merespon pelajaran yang diberikan oleh guru. Kemampuan siswa dalam mengembangkan ide ketika pelajaran menulis juga masih kurang. Adapun objek penelitian ini adalah kemampuan menulis puisi pada siswa. Dalam hal ini kemampuan menulis pada siswa kelas VIII C khususnya puisi masih sangat kurang.

Teknik pengumpulan data dalam penelitian ini menggunakan tes, observasi, wawancara, catatan lapangan, dan 
dokumentasi foto. Instrumen dalam penelitian ini berupa soal tes berbentuk produk yang berkaitan dengan materi puisi, lembar observasi dari pratindakan hingga pascatindakan siklus II, lembar catatan lapangan selama pembelajaran berlangsung, lembar wawancara, serta data dokumentasi foto.

Validitas data penelitian ini menggunakan triangulasi dengan cara tiga strategi yaitu melalui sumber, metode dan teori. Adapun teknik analisis data diolah dalam bentuk kuantitatif kemudian dianalisis secara deskriptif. Berikut persentase keterampilan menulis puisi: $\mathrm{SP}=$ $\frac{S K}{R} \times 100$

Keterangan:

SP : Skor Persentase

SK : Skor Komulatif

$\mathrm{R}$ : Jumlah Responden.

\section{Hasil dan Pembahasan}

Hasil penelitian diperoleh dari hasil tes dan nontes selama pembelajaran berlangsung. Hasil tes terdiri atas pratindakan, siklus I dan siklus II. Hasil penelitian yang berupa tes menulis puisi disajikan dalam bentuk data kuantitatif, sedangkan hasil penelitian yang berupa nontes disajikan dalam bentuk deskriptif data kualitatif. Data nontes yang dipaparkan dalam siklus I dan siklus II meliputi observasi, catatan lapangan, wawancara dan dokumentasi foto.

\section{Hasil Penelitian Tahap Pratindakan}

Pada tahap pratindakan dapat dilihat hasil menulis puisi yang dibuat oleh siswa dengan tema bebas. Siswa menulis puisi dengan alokasi waktu 2 jam pelajaran. Dalam hal ini, siswa terlihat kurang antusias dalam mengerjakan tugas. Kegiatan belajar mengajar kurang kondusif, salah satu faktornya adalah kondisi kelas yang berhawa panas pada saat jam pelajaran terakhir sehingga siswa kurang fokus dalam mencari ide. Selain itu, kondisi kelas juga terihat ramai saat siswa kesulitan dan saling bertanya kepada temannya. Ketika guru menyuruh siswa untuk bertanya mengenai kesulitannya, peserta didik justru diam dan tidak menghiraukan perintah dari guru. Pada saat setengah waktu dari dua jam pelajaran, hanya beberapa siswa yang sudah menyelesaikan tugas. Sementara bagi siswa yang sama sekali belum menulis puisi pada lembar kerjanya, ketika ditanya oleh guru, siswa mengaku sangat kesulitan dalam menentukan topik dan mengembangkan ide. Adapun perolehan skor keterampilan menulis puisi pada tahap pratindakan diperoleh nilai rata-rata siswa adalah 50,5.

Pada setiap aspek dalam penulisan puisi juga memiliki kriteria penilaian tersendiri dengan skor ideal yang sama yaitu 5. Dalam hal ini, pada aspek kesesuaian tema dengan isi mendapat nilai rata-rata 2,9. Skor rata-rata yang diperoleh pada indikator diksi pada saat tes pratindakan adalah 2,72. Skor rata-rata yang diperoleh pada indikator bahasa figuratif pada saat tes pratindakan adalah 2,34. Skor rata-rata yang diperoleh pada indikator kreativitas dalam mengembangkan ide saat pratindakan adalah 1,82 .

\section{Hasil Penelitian Tahap Siklus I}

Pada tahap siklus I respon siswa terlihat mengalami peningkatan dibandingkan dengan pada saat pratindakan. Selain itu, sudah terlihat bahwa siswa lebih siap dan fokus dalam pembelajaran khususnya menulis puisi. Saat pemberian materi dari guru, kondisi kelas sudah cukup 
kondusif, akan tetapi beberapa siswa masih terlihat pasif. Peserta didik belum berani mengajukan pertanyaan apabila mengalami kesulitan atau belum paham dengan materi yang diberikan guru. Namun yang menarik dari kagiatan siswa dalam siklus I ini adalah siswa tampak antusias dalam mencermati media pembelajaran yaitu berupa lembaran teks berisi lirik lagu Ramadhan Suci berbahasa Jawa beserta terjemahnya. Terlebih pada saat guru menyanyikan secara langsung di depan siswa, berbagai ekspresi siswa ditunjukkan. Sebagian ada yang tertawa, ada juga terlihat kebingungan mendengar lirik lagunya yang unik, dan yang lebih menarik adalah guru menemukan siswa sedang menggoyangkan sedikit kepalanya, Nampak seperti menikmati lagu Ramadhan Suci.

Peserta didik tidak saling mengganggu yang lain dan lebih fokus pada media yang diberikan kepadanya. Terkadang beberapa siswa saling bertukar pandangan untuk sekadar tersenyum menikmati lagu yang dinyanyikan oleh guru. Kemudian peserta didik menyimak penjelasan dari guru mengenai isi lagu tersebut. Ketika tiba saatnya bekerja secara berkelompok, siswa bergegas untuk berkumpul dengan anggota kelompoknya. Siswa membentuk grup-grup kecil dan melingkar meskipun sebenarnya masih terlihat bingung apa yang akan didiskusikan bersama teman kelompoknya. Guru menjelaskan terlebih dahulu mengenai isi lagu Ramadhan Suci, siswa terlihat baru pertama kali mengenal lagu tersebut. Hanya beberapa siswa yang mengetahui sekadar judulnya sehingga ketika guru menjelaskan isi lagu Ramdhan Suci terkesan mendapat pengetahuan baru, terlebih melihat pencipta lagu tersebut adalah seorang Kyai sesepuh di daerah tempat sekolah yaitu Buntet Pesantren. Namun pada saat mengerjakan tugas kelompok untuk menceritakan kebudayaan di daerah masing-masing, terlihat masih kebingungan dan tidak berani bertanya. Ketika guru merasa bahwa waktu yang dihabiskan terlalu lama, siswa baru berani mengeluh dalam mencari topiknya.

Selain itu, ketika siswa disuruh presentasi masih belum terlihat percaya diri dan saling nunjuk satu sama lain di dalam kelompoknya. Penampilan dari presentasi semua kelompok juga masih belum maksimal, suara kurang lantang dan masih terbata-bata. Untuk itu, bimbingan guru masih sangat diperlukan dalam pembelajaran menulis puisi siklus I ini agar berjalan dengan baik dan lancar serta tujuan pembelajaran dapat tercapai. Berikut ini lirik lagu tradisional "Ramadhan Suci":

Ramadhan suci Alhamdulillah

Wis teka maning wulan mulia

Wulan kang agung wulan kang utama

Wulan Al-Qur'an lan wulan ibadah Ayu sembahyang traweh lan sunnah

Tinggalen nafsu angkara murka Tingkah lan ngomong simg ati-ati Mempenga luruh ridhone Ilahi Lailatur Qodar turun Al-Qur'an Luwih utama sing sewu wulan Amal sawengi pahalane ngungkuli Amal terus sewu wulan bli mari Sawangen wong fakir lan wong miskin

Sue bli mangan terus prihatin Coba rasakena susah kemponge Supaya cukul melas lan sayange Delengen ayam selawase anggrem Sanggup puasa sanggup bli merem Masa menusa makhluk kang mulia Kalah ning ayam makhluk sederhana

Mulan wong kang gelem puasa Nahan nafsu lan penggawe ala 
Dibalekaken ning fitroh kang suci

Zakat fitrah lan bungah idul fitri

Takbiran bareng lan sembahyang

raya

Maaf-maafan salah lan dosa

Takbir lan tahmid agreng serta syahdu

Allahu Akbar wa lillahil hamdu

(Syakir, 2018:1)

Siswa yang kesulitan masih terlihat ragu bertanya pada guru tentang permasalahannya, tetapi ketika guru mendekatinya, siswa tersebut mulai berani bertanya. Interaksi sering terjadi antara guru dengan kelompok yang satu, dan juga dengan kelompok yang lain. Situasi kelas dengan menggunakan media lirik lagu tradisional Ramadhan Suci terlihat lebih menarik dibandingkan sebelum penggunaan media. Hal itu terlihat dari setelah siswa mendapat media, siswa lebih fokus pada pelajaran dan mengamati media. Sebelum mendapatkan media, siswa terlihat bingung dalam menulis puisi karena ide yang di cari tidak kunjung ditemukan. Suasana dalam kelas juga tampak lebih hidup dengan adanya kerja kelompok dengan pemanfaatan media lagu tradisional. Meski kelas terlihat riuh, namun bukan berarti siswa ramai sendiri (ribut). Keriuhan terjadi karena siswa saling berdiskusi dengan teman satu kelompoknya sehingga kelas terlihat menyenangkan dan tetap pada jalur pembelajaran menulis puisi meski siswa diberi kebebasan dalam berkreasi.

Pada saat mengerjakan tugas kelompok untuk menceritakan kebudayaan di daerah masing-masing, terlihat masih kebingungan dan tidak berani bertanya. Ketika guru merasa bahwa waktu yang dihabiskan terlalu lama, siswa baru berani mengeluh dalam mencari topiknya.
Hasil tindakan siklus I menunjukkan adanya peningkatan dibandingkan hasil tes awal (pratindakan), baik dari skor rata-rata maupun kemampuan siswa dalam menulis puisi. Peningkatan skor tersebut adalah $9 \%$. Keberhasilan tindakan secara produk tercermin dalam perolehan skor rata-rata menulis puisi siswa pada siklus I yang lebih meningkat jika dibandingkan saat pratindakan. Adapun perolehan skor keterampilan menulis puisi pada tahap siklus I diperoleh nilai rata-rata siswa adalah 72. Berikut ini tabel peningkatan skor keterampilan menulis puisi pada siklus I.

Tabel 4.4

Tingkat Keterampilan Menulis Puisi Sikus I

\begin{tabular}{|l|c|}
\hline \multicolumn{1}{|c|}{ Tingkat Keterampilan } & Skor \\
\hline Nilai tertinggi siswa & 80 \\
\hline Nilai terendah siswa & 52,5 \\
\hline Rata-rata nilai siswa & 72 \\
\hline
\end{tabular}

Berdasarkan data tabel di atas dapat diketahui bahwa keterampilan menulis puisi oleh siswa pada tahap siklus I sudah lebih baik jika dibandingkan dengan hasil pratindakan. Jumlah siswa yang mendapat skor dengan kategori sedang dan kategori cukup sudah mengalami peningkatan. Selain itu, pada siklus I ini sudah mampu menulis puisi dengan baik karena terdapat unsurunsur pembangun puisi seperti diksi yang sudah mencirikan puisi, gaya bahasa, pengimajian, dan persajakan. Meskipun masih ada beberapa kalimat yang belum padu serta maknanya membingungkan.

Proses pembelajaran pada siklus I secara keseluruhan mengalami perubahan ke arah yang lebih baik. Namun, peningkatan tersebut belum mencapai hasil yang diharapkan sehingga masih perlu adanya 
siklus tambahan agar hasil yang dicapai sesuai dengan harapan.

Pada aspek kesesuaian tema dengan isi mendapat nilai rata-rata 3,16. Skor ratarata yang diperoleh pada indikator diksi pada saat tes siklus I adalah 3. Skor rata-rata yang diperoleh pada indikator bahasa figuratif pada saat tes siklus I adalah 2,56. Skor rata-rata yang diperoleh pada indikator unsur kearifan lokal adalah 3,15 Skor ratarata yang diperoleh pada indikator kreativitas dalam mengembangkan ide saat tes siklus I adalah 1,95.

Pada masing-masing aspek penilaian, perolehan skor keterampilan menulis puisi oleh siswa terjadi peningkatan. Namun, hasil yang didapat belum mencapai Kriteria Ketuntasan Minimal (KKM) yang menjadi indikator keberhasilan. Hal tersebut masih terdapat kekurangan dalam karya siswa, yaitu pilihan kata dan ungkapan kadang-kadang kurang tepat tetapi tidak merusak makna. Selain itu, kesulitan dalam menentukan topik dan judul puisi yang membuat siswa tidak kebingungan dan tidak bersemangat karena sudah dibiasakan dengan menulis puisi bebas, sebelumnya belum pernah menulis puisi bertema kearifan lokal.

Hasil yang dicapai pada siklus I telah menunjukkan peningkatan meskipun ada beberapa kekurangan dan kendala. Permasalahan yang terdapat pada siklus I akan dicari jalan keluarnya dan akan dijadikan sebagai dasar perbaikan pada siklus selanjutnya sehingga hasil yang dicapai lebih memuaskan dan sesuai dengan indikator keberhasilan.

\section{Hasil Penelitian Tahap Siklus II}

Pada siklus II ini, terlebih dahulu guru mengajarkan materi yang belum sempat diajarkan pada siklus I serta mengulang kembali materi yang sudah diajarkan pada siklus I terutama tentang unsur-unsur pembangun puisi, siswa masih belum memahami mengenai diksi, majas, pengimajian, dan persajakan. Setelah itu siswa diminta mencermati dan menyimak lagu tradisional Ramadhan Suci yang diputar melalui speaker. Setelah menyimak lagu selama 4-6 menit, siswa dan guru saling bertukar pendapat tentang lagu Ramadhan Suci serta menganalisis nilainilai positif yang terdapat pada lagu tersebut. Tujuan dari pembelajaran ini adalah selain siswa dapat menyampaikan pemahamannya tentang lagu tradisional juga agar adanya pemahaman konsep tentang kearifan lokal di daerah tempat tinggal yang dijadikan sumber acuan dalam keterampilan menulis puisi.

Aktivitas yang dilakukan pada siklus II hampir sama dengan aktivitas yang dilakukan pada siklus I. Hanya saja pada siklus II, siswa dituntut untuk melakukan kerja atau aktivitas secara lebih mandiri serta diperkenankan bertanya kepada teman sebaya atau guru jika masih kesulitan. Siswa mulai melakukan diskusi dengan teman di sebelahnya pada tahap penyuntingan hasil karya puisi. Situasi pembelajaran di dalam kelas selama dilaksanakan tindakan pada siklus II menunjukkan adanya peningkatan.

Selain itu, peserta didik mulai terlihat lebih aktif dibandingkan dengan pada siklus sebelumnya. Siswa mulai bertanya bila mereka merasa kesulitan dalam menyerap pelajaran yang diberikan guru ataupun ketika peserta didik ingin mengajukan pendapatnya tentang media yang dipelajari. Peserta didik juga dengan sukarela mengangkat tangan bila diminta guru membacakan karya puisinya. Hal 
seperti itu belum pernah terjadi pada siklus sebelumnya. Pada siklus sebelumnya, peserta didik harus ditunjuk terlebih dahulu oleh guru bila akan menjawab pertanyaan maupun saat membacakan karya puisinya.

Peserta didik juga tampak lebih antusias dalam mengikuti pembelajaran dengan media lagu Ramadhan Suci. Hal ini dikarenakan karena metode yang dipakai pada siklus II berbeda dengan siklus I, jika pada siklus II siswa bertanya jawab secara langsung dengan guru sedangkan pada siklus I peserta didik lebih banyak bekerja secara berkelompok dan berdiskusi bersama teman kelompoknya.

Penggunaan media lagu tradisional 'Ramadhan Suci' pada pembelajaran puisi sangat membantu siswa kelas VIII C dalam mengatasi kesulitan yang dihadapi. Hal ini berpengaruh pada skor yang didapat pada siklus II. Skor keterampilan menulis puisi pada siklus II mengalami peningkatan jika dibandingkan dengan skor yang diperoleh pada tahap pratindakan dan tahap siklus I. Berikut ini tabel peningkatan skor keterampilan menulis puisi pada siklus II.

Tabel 4.6

\section{Tingkat Keterampilan Menulis Puisi}

Sikus II

\begin{tabular}{|l|c|}
\hline \multicolumn{1}{|c|}{ Tingkat Keterampilan } & Skor \\
\hline Nilai tertinggi siswa & 85 \\
\hline Nilai terendah siswa & 75 \\
\hline Rata-rata nilai siswa & 78,25 \\
\hline
\end{tabular}

Keterampilan menulis puisi oleh siswa pada tahap pascatindakan siklus II sudah mengalami peningkatan yang signifikan. Pada tahap ini seluruh siswa telah memperoleh skor di atas kriteria ketuntasan minimal. Pada akhir siklus II semua aspek dan kriteria dalam menulis puisi mengalami peningkatan. Selain itu, hasil penelitan mengalami peningkatan yang sangat memuaskan. Kualitas puisi siswa juga sudah baik.

Dari hasil pengamatan yang dilakukan berdasarkan diskusi dengan guru kolabortaor, dapat diketahui bahwa pembelajaran menulis puisi pada siklus II mengalami peningkatan sehingga tidak diperlukan lagi adanya tindakan pada siklus selanjutnya. Peningkatan dapat dilihat dari kualitas isi puisi yang dibuat oleh siswa, pada siklus II, semua aspek dalam keterampilan menulis puisi sudah baik. Siswa mampu mengembangkan unsur pembangun puisi serta menyesuaikan dengan tema yang dipilihnya sehingga isi puisi tampak menarik dan indah dibaca. Siswa mampu memanfaatkan potensi kata dengan baik.

Berdasarkan informasi yang diperoleh dari hasil penelitian siklus II, dapat diketahui bahwa peninkatan pada pembelajaran menulis puisi telah sesuai dengan yang diharapkan. Oleh karena itu, dapat disimpulkan bahwa media lagu tradisional "Ramadhan Suci" telah mampu meningkatkan keterampilan menulis puisi pada siswa kelas VIII C.

Skor rata-rata yang diperoleh pada aspek kesesuaian tema dengan isi mendapat nilai rata-rata 3,89. Skor rata-rata yang diperoleh pada indikator diksi pada saat tes siklus II adalah 3. Skor rata-rata yang diperoleh pada indikator bahasa figuratif pada saat tes siklus II adalah 3,39. Skor ratarata yang diperoleh pada indikator unsur kearifan lokal adalah 3,64. Skor rata-rata yang diperoleh pada indikator kreativitas dalam mengembangkan ide saat tes siklus II adalah 2,08. 


\section{Simpulan}

Proses pembelajaran menulis puisi cenderung monoton dan kurang menarik sehingga berpengaruh terhadap antusiasme dan motivasi siswa. Namun, setelah dilakukan implementasi tindakan melalui penerapan lagu tradisional "Ramadhan suci" dalam kegiatan menulis puisi pada siswa kelas VIII C MTsNU Putri 3 Buntet Pesantren Cirebon dapat meningkatkan antusiasme dan motivasi siswa dalam menulis puisi. Hal tersebut terlihat pada peningkatan kualitas proses pembelajaran menulis puisi. Pembelajaran puisi dengan menerapkan lagu tradisional "Ramadhan Suci" terlihat lebih menarik dan menyenangkan. Secara keseluruhan bahwa menerapkan lagu tradisional "Ramadhan Suci" dalam pembelajaran menulis puisi dapat meningkatkan kemampuan menulis puisi pada siswa. Hal tersebut dapat dilihat dari skor rata-rata tes menulis puisi dari tahap pratindakan hingga tes akhir pada siklus II yang mengalami peningkatan cukup signifikan yaitu pada tahap pratindakan adalah 50,5 ; pada siklus I meningkat menjadi 72 ; dan pada siklus II meningkat menjadi 78,25. Peningkatan tersebut selain terjadi pada skor rata-rata siswa, juga terjadi pada skor tiap aspek penilaian, yakni terdiri dari aspek isi meliputi aspek kesesuaian tema dengan isi, aspek diksi, aspek bahasa figuratif, aspek unsur kearifan lokal dan aspek kreativitas. Skor rata-rata siswa pada tahap pratindakan adalah 9,78; pada siklus I meningkat menjadi 13,82; dan pada siklus II meningkat menjadi 16 .

\section{Daftar Pustaka}

Alfiah. Dkk. (2009). Pengajaran Puisi Sebuah Penelitian Tindakan Kelas. Yogyakarta: Pustaka Pelajar.

Arikunto, Suharsimi, dkk. 2008. Penelitian Tindakan Kelas. Jakarta: Bumi Aksara.

Sukmadinata. Dkk. (2012). Metode Penelitian Pendidikan. Bandung: Remaja Rosdakarya.

Sulistyowati, R. (2011). Peningkatan Kemampuan Menulis Puisi Siswa Kelas VIII SMP Negeri 2 Homogede Melalui Teknik Clustering dengan Media Foto Jurnalistik. Dalam skripsi http://lib.unnes.ac.id diakses pada 07 November 2018 pukul 18.59 WIB.

Syakir. (2018). Lagu Kiai Fuad Hasyim tentang Ramadhan. Dalam file: https://www.buntetpesamtren.org/ diakses pada 25 Desember 2018 pukul 22.00 WIB. 